\title{
Disaster mitigation local wisdom in the tradition of the minangkabau community
}

\author{
Khairil Anwar ${ }^{1 *}$ \\ ${ }^{1}$ Literature of Minangkabau Department, Andalas University, Indonesia
}

\begin{abstract}
This study is about Minangkabau's local wisdom in disaster mitigation. Minangkabau is an ethnic and cultural group that is still alive and developing today. This ethnic group is centered in West Sumatra in the highlands of the Bukit Barisan which stretches along the island of Sumatra and develops through migrating to various regions in the world. This ethnicity is the oldest tribe on earth which is characterized by the use of the hereditary system according to the maternal or matrilineal line. His leadership made the Minangkabau ethnic have various kinds of local wisdom, especially those directly related to disaster mitigation. The Minangkabau cultural center is located in an area that has a high intensity of natural disasters by its natural topography. In responding to their natural environment, the Minangkabau community has local wisdom in the form of a superstructure that regulates infrastructure and social structure in disaster mitigation. This local wisdom is found in various literacy and traditions of the Minangkabau community. This qualitative discussion uses the perspective of cultural materialism theory. It was found that the local wisdom of disaster mitigation includes human norms and attitudes towards nature; norms before a disaster occurs; and post-disaster policies. To anticipate disasters, there are rules regarding the processing and utilization of nature, such as the use of land, hills, deserts, and swamps. In the event of a disaster, there are rules such as building rangkiang and filling it with food reserves, doing the ijok tradition, and batangeh.
\end{abstract}

\section{Introduction}

Minangkabau is an ethnic group that occupies an area centered in the central part of the Bukit Barisan on the island of Sumatra. The Minangkabau ethnicity occupies a cultural area, not an administrative area [1]. Currently, Minangkabau is known as culture, not administration. This central area is called darek. Darek is divided into three areas called Luhak Nan Tigo. In addition to the central area, there are development areas due to the increasing population and limited natural resources and energy in the area of origin. The area is called Ikua Darek Kapalo Rantau, and Rantau. Ikua Darek Kapalo Rantau is a transit area between darek and rantau. Meanwhile, overseas is a new local area to get a source of energy for their collective survival.

The Minangkabau cultural area is empirically located in the mountains, hills, valleys, rivers, lakes, and plains. Historically and oral tradition, this cultural area is described in tambo [2], local wisdom of Minangkabau origins, as follows:

Dari sirangkak nan badangkuang

Hinggo babuayo putiah daguak

Di sinan lagundi nan baselo
Di sinan banto nan barayun

Di sinan baringin sonsang

Dari sipisok-pisok pisau anyuik

Sampai ka pintu rajo ilia

Dari durian ditakuak rajo

Sampai ka sialang balantak basi

Dari aia babaliak mudiak

Sampai ka ombak nan badabua

Sailiran batang sikilang

Hinggo lauik nan sadidih

Rao jo Mapat Tunggua

Sarato gunuang maha lintang

Pasisia banda sapuluah

Hinggo taratak aian hitam

Sampai ka tanjuang simalidu

Pucuak jambi sambilan lurah

From crawling and snoring

Until there is a white crocodile with a chin

There's a cross-legged lagundi

There the swinging grass

There the beringin tree has hanging roots

From the Sipisok-pisok drifting knife

Up to Pintu Rajo Ilia

From Durian Ditakuak Rajo

Up to Sialang Balantak Basi

\footnotetext{
* Corresponding Author: khairilanwar@hum.gmail.ac.id
} 
From the water back to home

Until the crashing waves

In line Batang Sikilang

Until the surging sea

Rao and Mapat Tunggua

As well as Gunuang Mahalintang

Pasisia Banda Sapuluah

Until the Taratak Aia Itam

Up to Tanjuang Simalidu

Pucuak Jambi Sambilan Lurah

In the text above, it is explained about the process of the first arrival of the Minangkabau ethnic group to the region. This ethnicity came to this area by crawling and swinging. They crawl to climb high hills with sharp slopes or high inclines and cross valleys and rivers by swinging by utilizing hanging roots from trees in these locations. The traditional historiography also describes the natural conditions of Minangkabau which consist of hills, forests, rivers, and the sea. Culturally Minangkabau [3] Initially covered several administrative areas of the provinces in Indonesia, such as West Sumatra, North Sumatra, Aceh, Bengkulu, Jambi, and Riau, and several countries on earth such as Malaysia, Singapore, Brunei, and the Philippines. At this time of course it continues to grow in various provinces and countries along with the easy access to traffic both land, air, and sea and the mobility capabilities of the Minangkabau ethnic group [4]. However, when talking about the Minangkabau ethnicity, it is more related to the administrative area of West Sumatra Province. These cultural and administrative areas can be seen in the following map (Fig. 1).

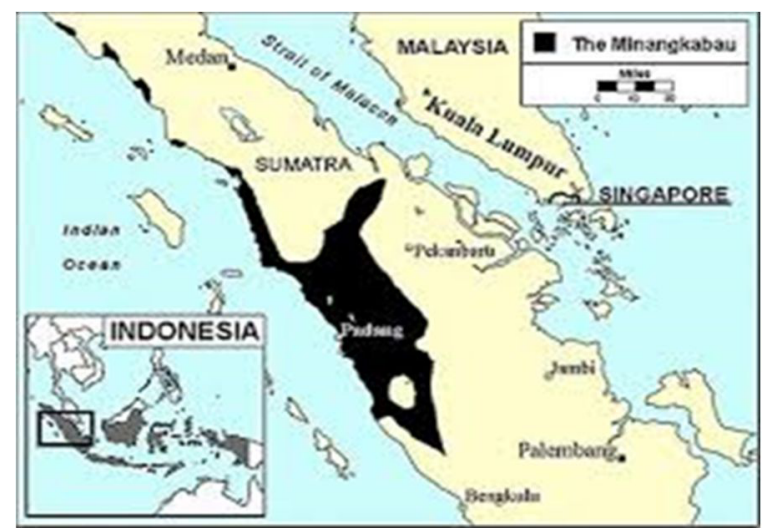

Fig. 1. Minangkabau Cultural Area Map.

Empirical facts in the form of the natural environment, traditions, and Tambo records present a fact that the Minangkabau ethnic area in West Sumatra is in an area with varied topography. The topography shows that the area has high potential and is prone to natural disasters [5]. As shown in the map in Fig. 2.

Minangkabau is the oldest ethnic group on earth. This old age is marked by the use of the hereditary system according to the maternal bloodline or matrilineal and tribal to the mother's tribe. The hereditary system was used by early humans for centuries past. His leadership makes the Minangkabau ethnic have various kinds of local wisdom that are familiar with nature. Wherever they live they always adapt to the natural situation that has existed first. The same as ancient humans who lived on the move, they came to new places by adjusting and only taking things according to their needs and not destroying nature.

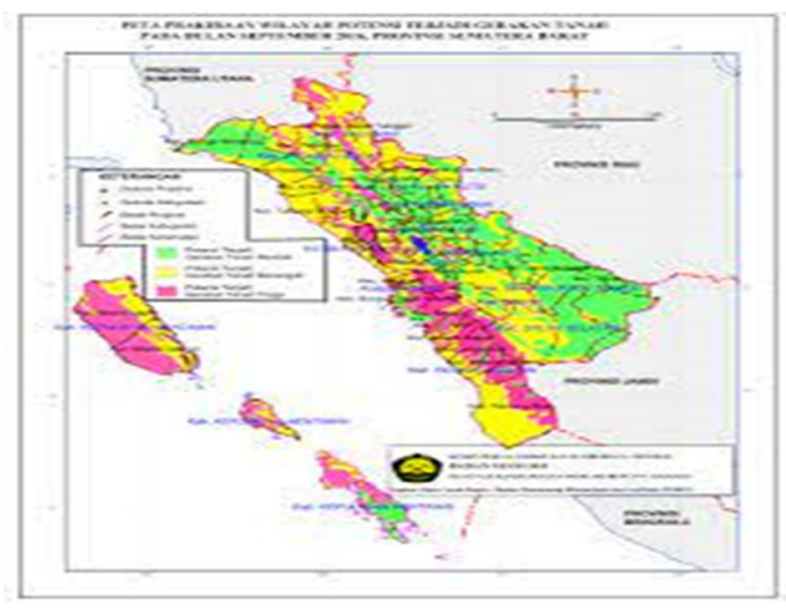

Fig. 2. Map of Disasters and Land Movements in West Sumatra

The philosophy "where the earth is stepped on there the sky is upheld" becomes a guide in the life journey of the Minangkabau ethnic group. Such a way of life so that they can be accepted everywhere they go [6]. They are not an exclusive type of ethnic group grouped in one place, by forming their ethnic identity in that place. This is directly related to their attitudes and behavior towards their natural and environmental conditions, becoming local intelligence or wisdom. A lot of their local wisdom is related to this nature, especially disaster mitigation.

How about Minangkabau local wisdom about disaster mitigation? This is what is discussed in this paper. This discussion is important to complete knowledge about disaster mitigation today, starting from the encyclopedia of knowledge and ethnic traditions that have existed for a long time and still exist today. This discussion is the result of research and studies on knowledge of oral traditions, stories, myths, and human behavior. All of that is a picture of his collective view in interacting with nature and preserving nature as a form of disaster mitigation.

\section{Method and Theory}

The data of this study were taken from various written data, oral traditions, oral stories, and myths as well as the traditional forms of Minangkabau human interaction with nature. The values contained in the data are called local wisdom. To explore these values, a certain method is used. This study was conducted using a qualitative method with the main objective of examining the uniqueness of the data to show Minangkabau local wisdom about disaster mitigation.

His study uses the perspective of the theory of cultural materialism formulated by Marvin Harris. Teori ini memandang bahwa bentuk, aktifitas, dan fungsi kearifan lokal mengandung tujuan dan makna. As an element of culture, it becomes a superstructure, structure, and 
infrastructure that is secretly [7] and hidden are recognized as norms and guidelines by the collective in their interactions.

Marvin Harris[8] applies this theory when trying to understand the cultural tradition of Hindus in India who deify the cow. He tried to dig and find out why Indian Hindus made and believed in cows as gods. The findings are that at first, cows in the community were a source of protein in the form of milk and cheese. In addition, cows are also a source of labor that helps humans cultivate large agricultural land. Meanwhile, the population is increasing and many cows are slaughtered for meat consumption. This condition worries community leaders and religious leaders. It could be, after a long time the cattle population will run out, so they will lose their source of protein and agricultural workers.

According to Harris, to maintain the cattle population, community leaders agreed in the form of a ban on cutting and eating beef. Prohibition is made the norm through suggestion and myth. The myth is embodied in various oral stories about cows as incarnations of gods who descended to earth, such as stories about the struggle for cheese with good and evil characters, and by eating cheese they become superhumans. In this regard, they perform various traditions and rituals against the cow, such as decorating the cow with clothes and various greatness attributes, giving the cows freedom to roam the village, worshiping and respecting cows, drinking cow urine and milk, and making certain days a religious day. with a cheese feast.

Myths and traditions that develop and run in a long and long time continuously from one generation to the next. It is still ongoing today as a religious belief and has become the culture of the Indian Hindu community. According to Harris, myths and oral stories are a form of the superstructure as a medium where ideas reside. The norms contained in it are the infrastructure that guides life and human interaction with humans, humans with their creators, humans with the surrounding ecology. Meanwhile, traditions and rituals are functional elements that build the social and cultural structure of Indian Hindu society.

\section{Results and Discussion}

Disaster mitigation implies an effort to reduce the risk and impact of disasters on communities in disaster-prone areas. Disasters can be in the form of natural disasters, man-made disasters, or a combination of both in a country or society [9]. There are four main things related to disaster mitigation, namely the availability of information and maps of disaster-prone areas; socialization and public awareness in dealing with disasters; knowing and setting actions that need to be taken and avoided if a disaster occurs at any time; structuring the area to reduce the threat of disaster[10]. Local wisdom is the intelligence of ideas, norms, and behavior of ethnic or ethnic groups that become traditions and continue from one generation to the next [7]. Local wisdom is found in various forms of oral traditions, myths, stories, and monumental works.
This disaster mitigation can be grouped into two types, namely structural and non-structural disaster mitigation [11]. Structural disaster mitigation is an effort to minimize the impact of natural disasters by building physical facilities by utilizing technology, such as building reservoirs to prevent flooding, building shelters for evacuation. Non-structural disaster mitigation is an effort to minimize the impact of disasters by making regulations and policies, such as disaster management laws, regulations on the use of spatial planning.

Local wisdom of disaster mitigation is the intelligence of ethnic groups who live in disaster-prone areas in responding to natural disasters that can occur at any time. The Minangkabau people who live in mountainous and hilly topographic areas have long had local wisdom in responding to their natural environment. There is local wisdom that is structural and non-structural. There are several forms of local wisdom of disaster mitigation in Minangkabau, such as rules for land use, building construction, building utilization rules, harvest management rules, and measures during epidemics and disasters.

Minangkabau ancestors were well aware that they lived in disaster-prone areas. Therefore, they regulate in such a way the management and use of land according to its contours [6]. The development and activities of community life are regulated by the nature of green moral or sustainable development, a development that is in favor of the future of the earth and human sustainability. The rules are contained in the collective image of the community which becomes the norm orally or in writing in the Tambo as follows:

Nan lereng tanami bambu jo tabu
Nan gurun jadikan ladang
Nan data jadikan parumahan
Nan payo jadikan ranangan itiak jo kabau
Nan bancah jadikan sawah
The slopes are planted with bamboo and sugar cane
The desert turns into fields
The flat is made into housing
The swamp is used as a place for herding ducks and
buffalo
The bancah turns into rice fields

The traditional text above contains local wisdom that regulates land use. Land that may be used as housing or settlements is naturally flat, not leveled land. Apart from that land, it must be maintained and maintained to maintain its ecological sustainability and benefit humans. Soil with steep slopes should be planted with bamboo and sugar cane. The bamboo and sugarcane plants are symbols. The bamboo is useful for binding and holding sloped soil from possible landslides and flooding. In addition, these plants are also useful for building houses and various purposes to support human life.

Likewise, other lands must be utilized according to the available contours. Deserted land is used as fields to plant horticultural crops, wasteful land is turned into rice fields for planting rice, and swampy land is used as a breeding ground for raising buffalo and ducks. Thus, the core of 
land use management is to avoid the threat of natural disasters from landslides and ground movement.

In building and managing settlements, it is regulated in accordance with the autonomy and independence of the village or nagari. There are several requirements in the form of infrastructure that must exist in a nagari [1] as follows:

\section{Nagari bakaampek suku}

Barumah gadang sambilan ruang

Salanja kudo balari

Sapakiak budak maimbau

Rangkiang baririk di halamannya

Rangkiang banamo sitinjau lauik

Sabuah banamo sibayau-bayau

Ciek banamo sitangka lapa

Jo rangkiang ketek di sampiangnyo

Babalai bamusajik

Balabuah batapian

Basasok bajarami

Bapandam pakuburan

In the Nagari, there are four tribes

Having a nine-room Rumah Gadang

The breadth of the horse can run in it

The size of the building is heard screaming children calling

The rankings line up on the page

Ranking named Sitinjau Lauik

One named Sibayau-Bayau

One named Sitangka Lapa

And the little ranking beside him

Has a hall and a mosque

Has roads and edges

Has springs and rice fields

Have a public cemetery

In the text above it is explained that in a Nagari there must be infrastructure and public facilities. The building is in the form of a Rumah Gadang as a place to live, a rank for storing food ingredients, a market or public meeting room, a mosque for worship, a road as transportation access, a bank as a place of purification and communication access, springs and rice fields as a source of food and energy, and a place to live. public cemetery to bury the dead.

The infrastructure required in the Nagari is in synergy with traditional disaster mitigation. Four Rangkiang were built in the yard of the Rumah Gadang house, used to store rice after harvesting, a s shown in Fig. 3). Each Rangkiang with rice in it is intended according to the food needs of the residents and the surrounding environment. One of the rangkiang is named Sitangka Lapa [1]. Rangkiang is used to store rice that is prepared before and used after natural disasters or humanitarian disasters such as the arrival of famine or famine, helping neighbors who are stricken by natural disasters, and serving food for refugees who pass by or come for shelter.

Likewise, other infrastructures in the form of roads, halls, mosques, banks, and cemeteries are part of the Minangkabau ethnic disaster mitigation strategy. Each of these infrastructures is used as a form of preparation for anticipating and post-natural disasters. Such infrastructure, especially road access for mobilization during and after a disaster is a major requirement in the current disaster mitigation perspective [12].

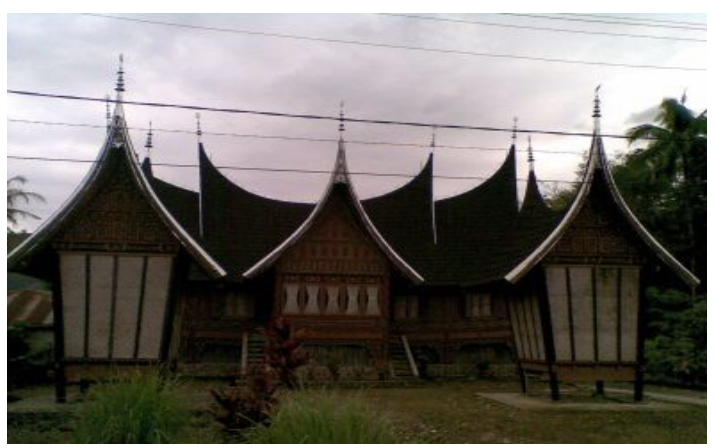

Fig. 3. Rangkiang and Rumah Gadang (Source: Doc)

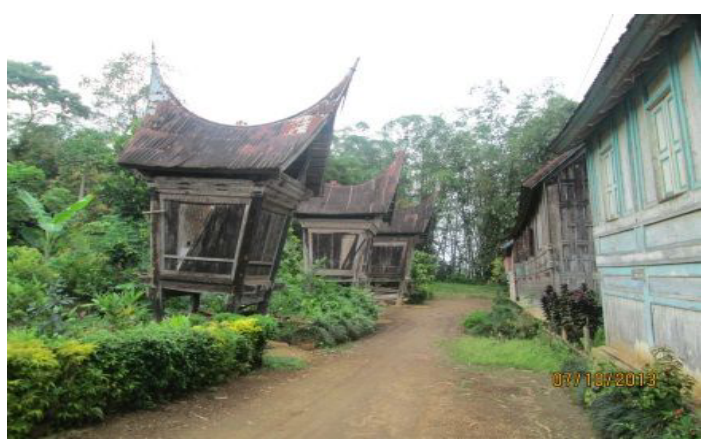

Fig. 4. Rangkiang in District Agam (Source: Doc)

When there is a pandemic and disease outbreak, the Minangkabau ethnic group has local wisdom to deal with it, namely Batangeh (Fig. 5). The Batangeh tradition is a way to treat members of the collective who are stricken with the disease. This tradition is carried out by placing the patient in a closed place and hot steam flowing from the results of boiling herbs in the form of spices. With this steamer method, it is hoped that the patient will recover from the plague.

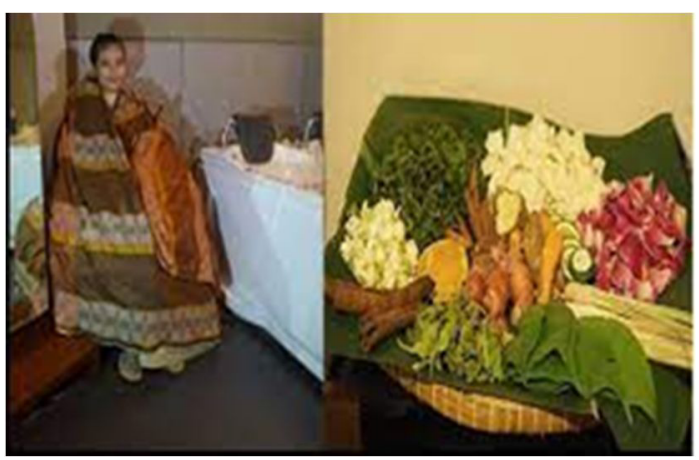

Fig. 5. Batangeh and Spices (Source: Google)

In addition, the series of Batangeh traditions are carried out in places and spaces that are far from the public, which is called baijok. Batangeh at the Baijok location aims to prevent the disease outbreak from spreading to other collective members. In addition to Batangeh, the Baijok location is used as a place of isolation for patients with epidemics of infectious diseases, such as tuberculosis, cholera, smallpox, leprosy, and corona. 
In addition to isolation during an epidemic disaster, this baijok tradition is also carried out to evacuate or flee from conflict or war areas (Fig. 6). The baijok tradition began during times of conflict or war with the Dutch colonialists. This tradition continued when the army attacked the central government of Indonesia against the people of West Sumatra who demanded equitable development in the early days of Indonesia's independence. People who were frightened and did not want to be caught fled to hiding places in caves or huts in the wilderness. This event is collectively called baijok.

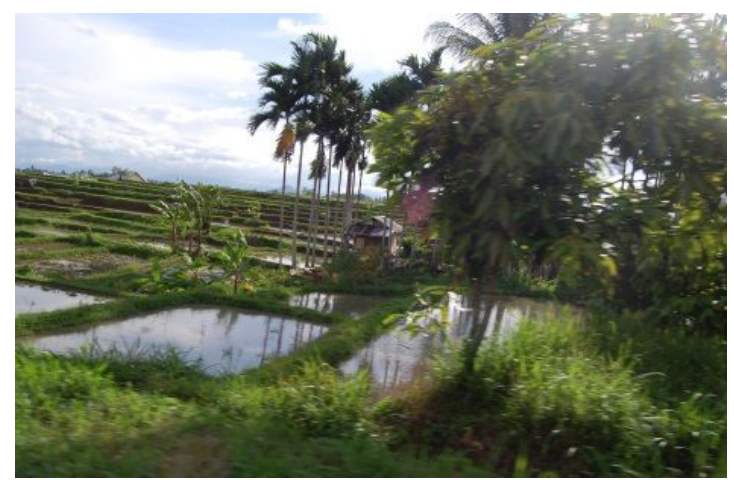

Fig. 6. Corona Isolation Pondok Baijok in Agam (Source: Doc)

\section{Conclusion}

Minangkabau's local wisdom on disaster mitigation has been around for a long time. Following the lineage system according to the mother's line used by ancient humans adopted by the Minangkabau ethnic group means that local wisdom in disaster mitigation has long existed. This disaster mitigation has become a reference in managing and utilizing natural potentials located in disaster-prone areas.

Local wisdom of disaster mitigation is structural and non-structural. Disaster mitigation is in the form of socializing the rules on how to use and manage land to prevent natural disasters; Rangkiang development as a complete infrastructure for post-natural disasters; preparing rice yields for times of famine and conflict; how to isolate during a disaster or baijok; and treatment during the epidemic or batangeh.

For the presence of this paper in scientific and academic activities, thank you to the Chairperson of the Andalas
University Research and Service Institute. This paper also refers to the results of previous studies that have been facilitated through research grants on Minangkabau ecological wisdom. Of course, thanks also to the 2021 ICDMM Committee who have worked hard and are willing to accept this article as part of the conference on disaster mitigation.

\section{References}

1 A. A. Navis, Nature Develops to Become a Teacher Jakarta: Grafitiperss, (1986)

2 H. D. Toeah, Tambo Alam Minangkabau. Pajakumbuh: Pertjetakan Limbago Pajakumbuh, (1968)

3 M. Naim, Merantau: The Migration Pattern of Minangkabau People's Migration Yogyakarta: Gajah Mada University Press (1979)

4 T. Kato, Indigenous Minangkabau and Merantau in Historical Perspective, 1st ed. Jakarta: Balai Pustaka (2005)

5 BNPB, "A Study on Natural Disaster Management in Indonesia," Orient. Consult. Co., Ltd. Asian Disaster Reduct. Cent., 2-2, Japan International Cooperation, 189 (2009)

6 M. Nasroen, Basic Minangkabau Customary Philosophy, 2nd ed. Djakarta: Star Moon (1971)

7 K. Anwar, "Ecological Wisdom of Oral Tradition: Surface and Deep Structure Tension in Preserving the Lake Environment," IOP Conf. Ser. Earth Environ. Sci., 469, 1 (2020)

8 S. K. Sanderson, Sosiologi Makro, 2nd ed. Jakarta: Raja Grafindo Persada. (1995)

9 K. Kim, "Technologies for Disaster Mitigation," Cell, no. March, 27-30 (2009)

10 Commonwealth of Australia, "National Disaster Risk Reduction Framework," 1-23 (2018)

11 D. Triana, T. S. Hadi, and M. K. Husain, "Disaster Mitigation Through Cultural and Structural Approaches," Semin. Nas. XII "Technology Engineering. eng. and Inf. 2017", 379-384 (2017)

12 S. Aminatun, "Study of Landslide Disaster Risk Analysis as a Basis," J. Tek., 22, 2, 372-382 (2017) 